309 小児㳎出性中耳炎の治療における扁摘の有用性

花田 誠 1)，園田 聡 2)，北嶋和智 2)

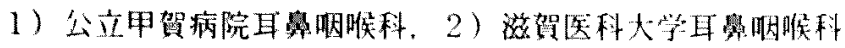

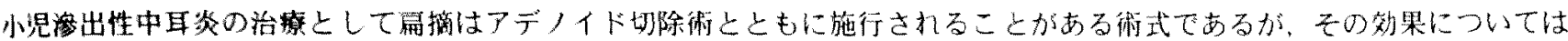
従来より議論のあるところである，その理由の一こして，從来の経回的アデノイド切除術においては园目的な手技のためア

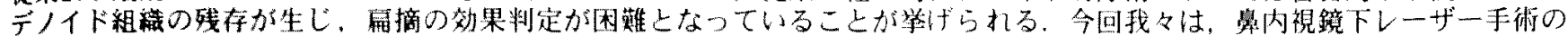

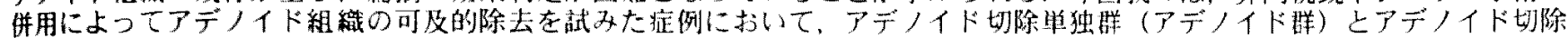

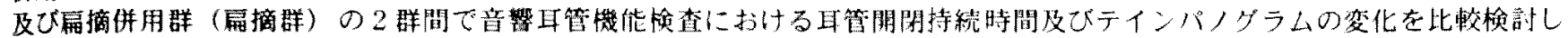



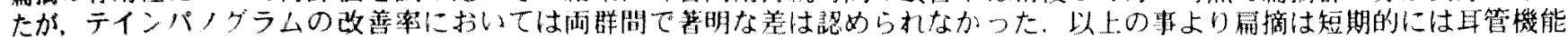

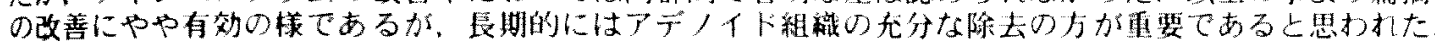

310 同種鼓膜を利用した着着性中耳㷋等の一期的手術

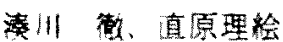

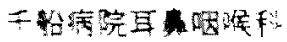

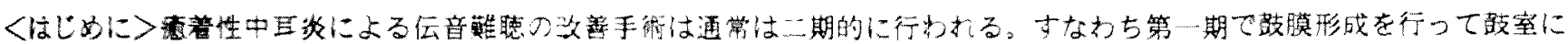

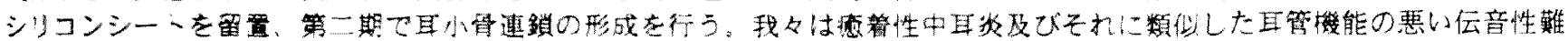

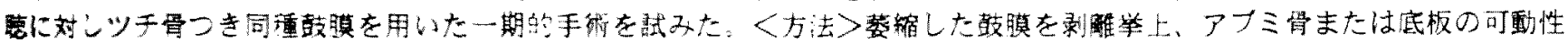

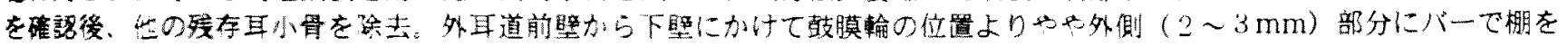

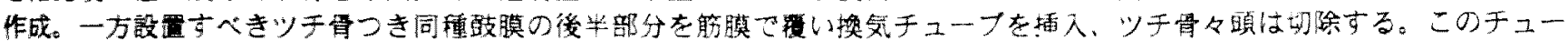

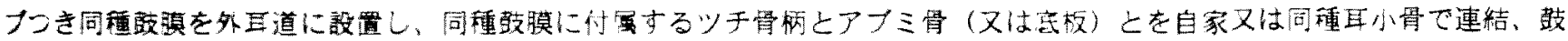

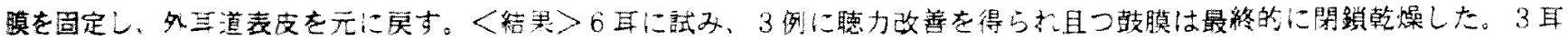

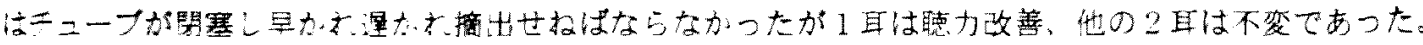

311 鼓案形成術(型の兴後聴力

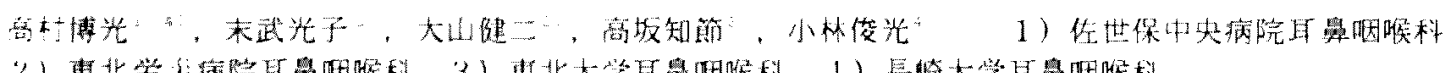

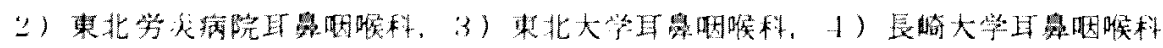

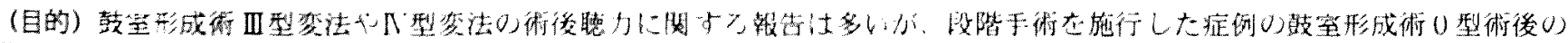

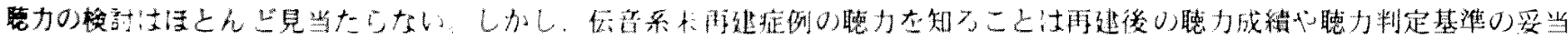

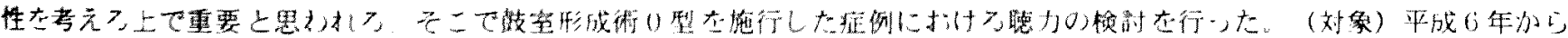

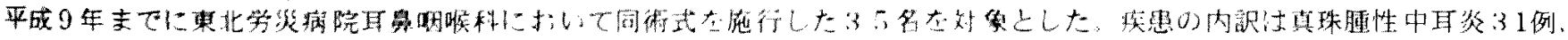

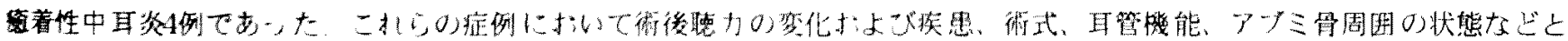

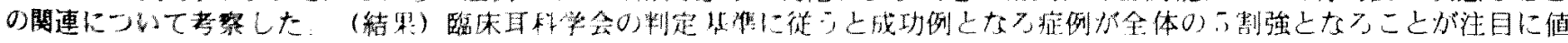

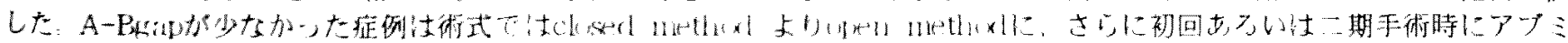

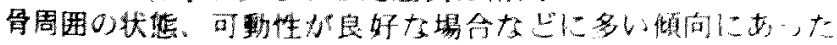

\title{
31 両側慢性中耳炎に対する両側同日手術
}

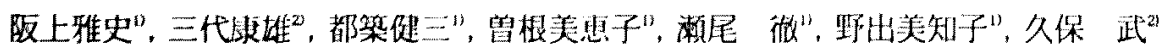

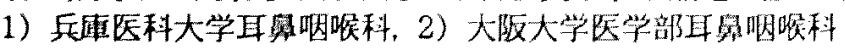

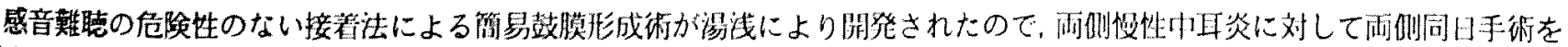

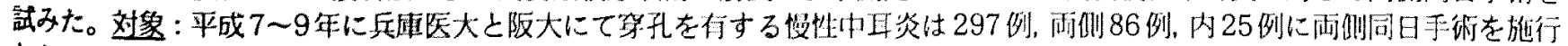

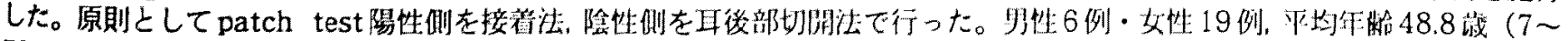

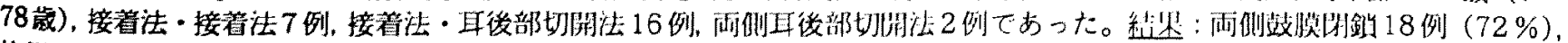

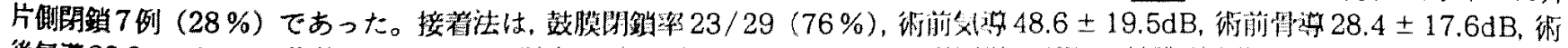

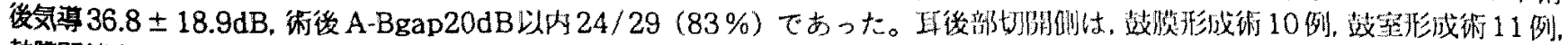

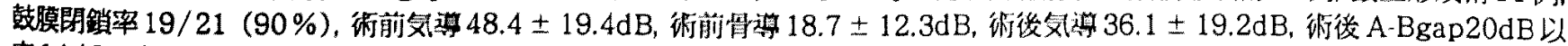
内14/21 (67\%) であった。結嗐：㱏例を選へば両倒同日手術は可能であると考えられた。 